(c) American Dairy Science Association, 2003.

\title{
Effectiveness of an Internal Teat Seal in the Prevention of New Intramammary Infections During the Dry and Early-Lactation Periods in Dairy Cows when used with a Dry Cow Intramammary Antibiotic
}

\author{
S. Godden, ${ }^{*}$ P. Rapnicki, ${ }^{*}$ S. Stewart, ${ }^{*}$ J. Fetrow, ${ }^{*}$ \\ A. Johnson, $¥$ R. Bey, $\dagger$ and R. Farnsworth* \\ ${ }^{*}$ Department of Clinical and Population Sciences, and \\ †Department of Veterinary Diagnostic Medicine, \\ Veterinary Teaching Hospital, University of Minnesota, \\ St. Paul 55108 \\ ‡Total Herd Management Services, Clintonville, WI 54929
}

\section{ABSTRACT}

The objectives of this study were to determine the effect of infusion with an internal teat seal at dry off, when used as an adjunct to long-acting antibiotic infusion at dry off, on the risk for acquiring a new intramammary infection (IMI) during the dry period, prevalence of IMI and linear score (LS) after calving, and risk for experiencing a clinical mastitis event between dry off and 60 DIM. A total of 437 cows from 2 dairy herds, with no clinical mastitis and 4 functional quarters, were enrolled at dry off. Prior to the final milking, all quarters were sampled for bacteriological culture and SCC analysis. After milking, all 4 quarters were infused with a commercially available long-acting dry cow antibiotic. Two contralateral quarters were then infused with an internal teat seal (Orbeseal, Pfizer Animal Health, New York). Following calving the teat seal was stripped out at first milking. Duplicate milk samples were collected between 1 to 3 DIM and again between 6 to 8 DIM for culture and SCC analysis. Quarters treated with Orbeseal had significantly lower prevalence of IMI at 1 to 3 DIM (tx = $22.8 \%$, control $=29.1 \%$ ), had significantly fewer quarters that acquired a new IMI between dry off and 1 to 3 DIM ( $\mathrm{tx}=20.2 \%$, control $=25.4 \%$ ), and had significantly fewer quarters affected by a clinical mastitis event between dry off and $60 \mathrm{DIM}(\mathrm{tx}=5.9 \%$, control $=8.0 \%$ ). Multivariable analysis showed a significant effect of treatment, with treated quarters being $30 \%$ less likely to develop a new IMI between dry off and 1 to 3 DIM, $31 \%$ less likely to have an IMI present at 1 to 3 DIM, 33\% less likely to experience a clinical

Received February 11, 2003.

Accepted July 8, 2003.

Corresponding author: S. Godden; e-mail: godde002@umn.edu. mastitis event between dry off and 60 DIM, and having significantly lower linear score measures at 1 to 3 DIM and 6 to 8 DIM, compared with control quarters.

(Key words: internal teat seal, mastitis, dry period)

Abbreviation key: CMT = California Mastitis Test, DCT = dry cow antibiotic therapy, LS = linear score, TMF = transition management facility.

\section{INTRODUCTION}

The mammary gland is particularly susceptible to new IMI during the early dry and late dry periods, correlating with involution and colostrogenesis, respectively (Smith et al., 1985; Eberhart, 1986; Todhunter et al., 1991; Hogan and Smith, 1998; Bradley and Green, 2000; Green et al., 2002). Some factors affecting this risk may include level of milk production at dry off, rapidity of udder involution, teat end condition, and level of contamination of teat ends (Oliver and Sordillo, 1989; Williamson et al., 1995; Dingwell et al., 2003). A major factor allowing the invasion of pathogens into the gland during the dry period may be that there is often a significant delay in the formation of a complete keratin plug in the streak canal (Comalli et al., 1984; Williamson et al., 1995; Dingwell et al., 2003). In one study, Williamson et al. (1995) reported that 50 and $5 \%$ of teats had an incomplete keratin plug present after 7 and $50 \mathrm{~d}$ of the dry period, respectively. Dingwell et al. (2003) reported that 50 and $23 \%$ of teat ends were still open after 1 and 6 wk of the dry period, respectively. The latter study reported that quarters that remained open and quarters that had cracked teat-ends were both $1.7 \times$ more likely to develop new IMI during the dry period compared with quarters that closed and that were not cracked (Dingwell et al., 2003). The practice of blanket dry cow antibiotic therapy (DCT), treatment of all quarters with a long-acting antibiotic at dry off, has 
been successful in curing many existing subclinical infections as well and offering short-term protection against new IMI when susceptible pathogens invade the gland during the early dry period (Natzke, 1981; Browning et al., 1990; Bradley and Green, 2001). However, new IMI may still occur if invading pathogens are not sensitive to the active ingredients in the antibiotic preparations being used and/or the antibiotic does not persist at therapeutic levels throughout the entire dry period (Smith et al., 1985; Bradley and Green, 2001).

One management tool that may be used to prevent new IMI during the dry period is an external teat sealant (Timms, 1997; Leslie et al., 1999; Lim et al., 2000). Once applied, these products dry to generate a latex, acrylic, or other polymer-based film over the teat that prevents entry of pathogenic bacteria into the teat canal. Timms et al. (1997) reported that 1 product persisted for more than $3 \mathrm{~d}$ on $98 \%$ of teats and, with periodic reapplication, showed a reduction of up to $68 \%$ in new IMI at calving. However, the extra labor and facilities required to frequently reapply these products may limit their potential for routine use on many dairies. An alternate management tool may be the use of an internal teat seal. Orbeseal is an internal teat seal consisting of bismuth subnitrate in a paraffin base (65\% wt/wt, $2.6 \mathrm{~g}$ in $4 \mathrm{~g}$ ) (Pfizer Animal Health, New York, NY). This inert viscous paste is infused into the quarter at time of dry off forming an immediate physical barrier in the distal portion of the teat cistern to prevent bacteria from ascending through the teat canal. Insoluble in milk, it has no antimicrobial properties and no residue or food safety risks (C.V.M.P., 1999). Woolford et al. (1998) reported that, of 19 treated quarters that were X-rayed, all had the internal teat seal present in the base of the teat sinus at 100-d dry. The majority of the Orbeseal product is stripped out at first milking after calving, with some residual product removed in the subsequent several milkings after calving. This teat seal is currently approved and in use in the United Kingdom and New Zealand under the trade name TeatSeal (Cross Vetpharm Group Ltd., Ireland; Bimeda Ltd., Auckland, NZ).

Studies in New Zealand and the United Kingdom have demonstrated that, when infused as the sole treatment in uninfected quarters at dry off, this internal teat seal has equal, if not better, efficacy in preventing new IMI during the dry period, compared with DCT (Woolford et al., 1998; Berry and Hillerton, 2002; Huxley et al., 2002). Thus, an internal teat seal may be useful as an alternative to DCT for the prevention of new IMI during the dry period, when infused into uninfected quarters at dry off. Successful implementation of this strategic treatment approach may be a challenge, however, in many North American dairy herds. Strategic infusion of quarters with an internal teat seal alone will require careful attention to infusion techniques to avoid introducing pathogens into an unmedicated quarter. Quarters that are infected at dry off would still require DCT to achieve elimination of these existing infections. Furthermore, because there is still no quick, simple, inexpensive, and accurate on-farm method to differentiate uninfected from infected quarters at time of dry off, the standard industry recommendation of blanket DCT is likely to continue. If this assumption is correct, then the next obvious question is whether there would be a benefit to using an internal teat seal as an adjunct to DCT at dry off. Ultimately this benefit should be measured from both an udder health and an economic standpoint.

The objective of this study was to describe the effectiveness of Orbeseal in the prevention of new IMI during the dry and early lactation period when used as an adjunct to DCT at dry off. The primary hypothesis was that quarters treated with DCT and Orbeseal at dry off would be at lower risk for acquiring a new IMI between dry off and calving compared with quarters treated with DCT alone. Secondary hypotheses were that quarters treated with Orbeseal and DCT at dry off would be at lower risk for presence of an IMI after calving, lower risk for experiencing a clinical mastitis event between dry off and 60 DIM, and have a lower linear score (LS) after calving compared with quarters treated with DCT alone.

\section{MATERIALS AND METHODS}

\section{Dry-Off Enrollment, Treatment Assignment, and Sampling Strategy}

Study participants included 2 commercial free-stall Holstein dairy herds in western Wisconsin, milking a total of approximately 2500 cows; 1000 from herd A and 1500 from herd B. To be eligible for enrollment, cows had to be located at the home farm for at least 3 mo prior to dry off, have received no parenteral or intramammary antibiotic or antiinflammatory treatments within $30 \mathrm{~d}$ prior to dry off, have a projected dry period between 28 and $100 \mathrm{~d}$, and have 4 functional quarters with no clinical mastitis present on the day of dry off. Teat end condition was not evaluated or considered among the inclusion/exclusion criteria.

Cows due to be dried off were brought into the parlor as a group, once per week on each dairy, for their last milking and routine DCT. Cows were visually identified using duplicate ear tags. Following teat preparation using the farm's usual premilking routine, which included predipping with a $0.5 \%$ iodine-based teat dip, 
a California Mastitis Test (CMT) was performed on all four quarters (CMT results not reported in this paper). California Mastitis Test results were not used to exclude cows from enrollment. Teat ends were then scrubbed with a 70\% alcohol-soaked gauze and 3 foremilk samples aseptically collected from each quarter and placed directly into a chilled cooler (on ice). Immediately following the final milking, all four quarters were again scrubbed with an alcohol-soaked gauze and then routinely dry treated by infusion of DCT [Orbenin-DC; Cloxacillin (benzathine), $500 \mathrm{mg}$ (ScheringPlough Corp., Kenilworth, NJ). All four quarters were massaged after DCT infusion. The treatment of infusion with Orbeseal was then randomly assigned to two contralateral quarters ( $\mathrm{LH} / \mathrm{RF}$ or $\mathrm{LF} / \mathrm{RH})$ based on a randomly generated treatment assignment scheme that was established in advance and which began with the first cow entering the parlor. The alternate two contralateral quarters remained as control quarters. Orbeseal treatment involved rescrubbing the teat end with an alcohol-soaked gauze and then infusing the Orbeseal tube. The teats and quarters were not massaged after infusing the Orbeseal. Following treatment all teats were postdipped with a $1 \%$ iodine-based teat dip and the cows then moved to a freestall pen where they were observed between 1 and $4 \mathrm{~h}$ posttreatment for signs of adverse reactions.

\section{Management of Dry and Fresh Cows}

Dry cows were housed in either a pasture-based management system or free-stall facility until approximately 4 wk prior to the anticipated calving date when moved to a transition management facility (TMF). The TMF was a 400-stall sand free-stall facility operated by the same owner of the participating milking dairies and managed in partnership with the College of Veterinary Medicine, University of Minnesota. Cows calved in individual maternity pens. Postcalving processing included attaching a collar with unique ID transponder, $473 \mathrm{ml}$ Propylene Glycol P.O., $500 \mathrm{ml}$ of $23 \%$ calcium borogluconate solution I.V., manually fore-stripping all 4 quarters followed by colostrum collection, and then relocation into a lactating-cow pen. Cows remained at the TMF until between 10 to 14 DIM, at which time healthy cows were transported back to their dairy of origin.

\section{Posttreatment Sampling and Records}

Postcalving milk samples were collected from all quarters in the parlor, once between 1 and 3 DIM, and once between 6 and 8 DIM. Quarters were routinely prepped for milking, a CMT test performed, and, fol- lowing cleaning of teat ends with a $70 \%$ alcohol-soaked gauze, 3 separate foremilk samples collected and then immediately chilled on ice. All clinical mastitis events and all culling, death, other disease, and treatment events occurring during the dry period and up to 60 DIM were recorded into on an-farm record keeping system used on all three sites (DairyComp305; Valley Agricultural Software, Tulare, CA). Milk samples were collected from all clinically affected quarters by farm staff at the time of detection.

\section{Milk Sample Analysis}

Somatic cell counts. One of the three quarter milk samples collected at the dry off, 1 to 3 DIM, and 6 to 8 DIM sampling points was preserved with a bronopol tablet (2-Bromo-2-Nitro-Propane-1,3 Diol: $6 \mathrm{mg} / \mathrm{tab}-$ let), refrigerated, and then submitted unfrozen twice per week for SCC testing (MN DHIA Laboratory, Zumbrota, MN). Testing was performed using the Fossomatic 5000 SCC Instrument (Foss North America, Inc. Eden Prairie, MN), using Opto Electronic Fluoro Flow Cytometry with ethidium bromide and buffer solution in staining of the white cells.

Laboratory bacteriological culture. The 2 other duplicate milk samples collected at each sampling point were frozen and then submitted, once per week, for bacteriological culture (Laboratory for Udder Health, University of Minnesota, St. Paul, MN). One sample from each set of duplicate milk samples from individual quarters was thawed and, while still cold, $0.1 \mathrm{ml}$ was plated onto MacConkey agar and Factor agar using sterile cotton tipped swabs (N.M.C., 1999). Factor Agar, similar to K.L.M.B. agar (Beatty et al., 1985), selects for gram-positive organisms while inhibiting the growth of gram-negative bacteria with antibiotics (Factor agar patent in process, University of Minnesota). A 0.1-ml inoculum volume was used to improve sensitivity (Buelow et al., 1996; Lam et al., 1996; N.M.C., 1999). Inoculated plates were incubated at $37^{\circ} \mathrm{C}$. After incubation for 18 to $24 \mathrm{~h}$, all plates were observed for microbial growth. Those plates having growth were recorded and identification started. All plates were placed in the incubator for an additional 36 to $48 \mathrm{~h}$ and reevaluated for microbial growth. Colonies on MacConkey agar plates were presumptively identified based on colony morphology and colony color was used as a means of determining if the organism on the plate was a lactose-fermenting organism. Isolates were also gram stained to assist in organism identification. Organism identity was confirmed using the API $20 \mathrm{E}$ test (bioMerieux-Vitek, Inc. Hazelwood, MO). Colonies suspected as being staphylococci based on morphology were confirmed as staphylococci based on cat- 
alase reaction and microscopic morphology. Organisms suspected of being Staphylococcus aureus were confirmed using the tube coagulase reaction. Those organisms that were catalase-positive and coagulasenegative were classified as Staphylococcus spp. Catalase-negative streptococci were streaked onto TKT medium, which is selective for Streptococcus spp. only, to determine the esculin reaction and presumptive identification prior to organism confirmation using the API Streptococcus identification system (bioMerieuxVitek, Inc. Hazelwood, MO).

On-farm culture of clinical cases. Milk samples collected from clinically affected quarters were cultured using an on-farm triplate culture system (Minnesota Easy Culture System II, 2000) and the results entered into the on-farm DairyCOMP 305 record-keeping system (Valley Agricultural Software). The 3 media used in the Tri-plate system include Factor, TKT, and MacConkey agars. This allows the differentiation of gram-positive from gram-negative pathogens and the differentiation between Staph. aureus and Streptococcus species. Further speciation is facilitated by comparing colony morphology to color photographs provided in a laboratory manual. This on-farm system was already in routine use on study sites prior to initiating the study. In an effort to improve the quality of results from these on-farm cultures, one person on each of the three sites was made responsible for plating and then interpreting the culture results for all clinical mastitis events. These individuals were trained in culture and interpretation techniques by one of the study's principle investigators and all were provided with a manual, including color photos, which described culture methods and interpretation guidelines.

\section{Data Analysis}

Chi-square analysis (Fisher's Exact Test; Proc FREQ in SAS, version 8.0) and multivariate logistic binomial regression (Proc GENMOD in SAS, version 8.0) were used to investigate the relationship between treatment group (explanatory variable) and each of the following 4 dependent variables of interest:

1) Risk for presence of an IMI at dry off, 1 to 3 DIM, and 6 to 8 DIM (three time points analyzed separately). An IMI was defined as the isolation of 1 or 2 bacterial pathogens from a quarter milk sample. A sample was considered contaminated if 3 or more bacterial pathogens were isolated from the same sample, in which case the second (duplicate) sample was cultured (Bradley and Green, 2000; Huxley et al., 2002; Green et al., 2002). If the second sample was also contami- nated, the results for that quarter were omitted from final analysis. Five percent of quarters cultured contained mixed results ( 2 or more pathogens), and $0.5 \%$ of quarters cultured were omitted from analysis because of contamination. In cases of mixed infections, a quarter was only counted once as being infected. However, all bacterial pathogens isolated were reported in the results.

2) Risk for developing a new IMI between dry off and 1 to 3 DIM, or between dry off and 6 to 8 DIM (2 time intervals evaluated independently). A new IMI was defined as the appearance of bacterial growth at either 1 to 3 DIM or 6 to 8 DIM in a quarter that was not previously infected at dry off, or the presence of a different bacterial pathogen after calving compared those pathogens present at dry off (Huxley et al., 2002). In cases of mixed infections, a quarter was counted only once as having a new IMI, even if 2 new bacterial pathogens were cultured. However all new bacterial pathogens isolated were reported in the results.

3) Risk for experiencing a clinical mastitis event between dry off and 60 DIM. A clinical mastitis event was defined as the presence of visibly abnormal milk (plus/minus abnormal quarter or signs of systemic illness). A quarter experiencing one or more cases of clinical mastitis during the period between dry off and 60 DIM was classified as a positive mastitic quarter.

4) Risk for experiencing a cure between dry off and 1 to 3 DIM. A cure was defined as the disappearance of growth of one or more bacterial pathogens at 1 to 3 DIM that had previously been present at dry off. By definition, it was possible for a cure (for one bacterial pathogen) and a new IMI (for a different bacterial pathogen) to occur in the same quarter.

Analysis of bacteriological culture and clinical mastitis event data was first performed for all pathogens (overall), and then repeated for each of 5 general pathogen subgroups: major pathogens, minor pathogens, contagious pathogens, environmental streptococcal species, and gram-negative pathogens.

Major pathogens included: Staph. aureus, Streptococcus agalactiae, Streptococcus dysgalactiae, Streptococcus uberis, Streptococcus bovis, Enterococcus spp., Escherichia coli, Klebsiella spp., Proteus spp., Enterobacter spp., Citrobacter spp., Bacillus spp., Pseudomonas spp., and yeast. Minor pathogens included Corynebacterium bovis and CNS. Staphylococcus aureus and Strep. agalactiae were defined as contagious pathogens. The environmental streptococcal species group 
included Strep. dysgalactiae, Strep. uberis, Strep. bovis, and Enterococcus spp. The environmental gramnegative pathogen group included Enterococcus spp., E. coli, Klebsiella spp., Proteus spp., Enterobacter spp., Citrobacter spp., and Pseudomonas spp.

Multivariate linear regression (Proc MIXED in SAS, version 8.0) was used to examine the relationship between treatment group (forced explanatory variable) and LS at dry off, 1 to 3 DIM, and 6 to 8 DIM (dependent variables). Least squares mean estimates for LS were reported in the results.

A random term for cow was included in all logistic and linear regression models to account for the effect of clustering of quarters within cow. Farm level variation was accounted for by including 'herd' as a fixed effect in all models. Additional covariates were included in multivariate models if univariate analysis of the relationship between these covariates and the dependent variable of interest resulted in a $P<0.25$. Interaction terms were investigated in all models between treatment and all other significant covariates. Final significance for testing the effect of treatment group was established at $P<0.05$.

Clinical mastitis event data were analyzed using both the multivariate logistic regression approach (Proc GENMOD) (described in earlier paragraph) and a Cox proportion hazards regression model (PHREG procedure in SAS, version 8.0) to describe the survival distribution function for treated vs. control quarters for experiencing a case of clinical mastitis. For the latter analysis, the date of origin was defined as the dry-off date and the failure date was defined as the date when a quarter was first reported to be affected by a clinical mastitis event. Quarters were considered to be at risk of a clinical mastitis event only once during the period between dry off and 60 DIM. Quarters were classified as censored at either the cow's reported cull or died date, or 60 DIM, which ever came first. This regression model building approach (Proc PHREG) was the same as for the multivariate logistic regression models previously described (Proc GENMOD), in that it controlled for appropriate covariates. It also controlled for within-cow clustering of quarters by specifying the Covsandwich(aggregate) statement in the procedure statement and then specifying cow as the level of aggregate $(i d=c o w)$. A plot of the estimated survival distribution function was created for days to a clinical mastitis event for control and treated quarters.

\section{RESULTS}

Of 437 cows (1748 quarters) initially enrolled at dry off between March 27, 2002, and August 1, 2002, 419 cows remained in the study, calving between May 11,
2002, and October 5, 2002. Three cows were omitted from final analysis because their dry period was fewer than $28 \mathrm{~d}$ in length. The remainder were removed from the study prior to calving primarily because of death or culling due to a variety of common disease ailments. Mastitis was not reported for any of the cows leaving the study prior to calving. Therefore, there should have been little opportunity for the introduction of bias due to inappropriate omission of treatment failures from the final analysis. Cows enrolled from herd A $(n=239)$ and herd B $(n=180)$ were producing an average of 19.6 (1.4 to 39.4 ) and $14.7(0.8$ to 36.9$) \mathrm{kg}$ of milk $\cdot \operatorname{cow}^{-1} \cdot \mathrm{d}^{-1}$, respectively, at dry off. Mean dry period length was $55.5 \mathrm{~d}$ (33 to 97).

\section{Linear Score and IMI Status at Dry Off}

The prevalence of IMI (overall) in treated and control quarters at dry off was 31.1 and $33.3 \%$ (Table 1), respectively, and the LSMean LS at dry off was 5.4 ( \pm 0.08 ) for both treated and control quarters. Neither of these parameter values were statistically different between treated and control quarters $(P>0.05)$, indicating that the randomization procedure used for treatment allocation was successful. Quarters had significantly higher LS measures at dry off if they were infected with either a major pathogen species (estimate \pm S.E. $=0.76 \pm 0.10$ ) or a minor pathogen species $(0.54 \pm 0.11)$, as compared to LS in uninfected quarters. There was a negative relationship between LS and milk yield $(\mathrm{kg} / \mathrm{d})$ at dry off $(-0.13 \pm 0.007)$, and a positive association between LS and parity $(0.28 \pm 0.05)$.

\section{Effect of Treatment on Risk for Presence of an IMI at 1 to 3 DIM and 6 to 8 DIM}

The proportion of quarters with an IMI (overall) present was significantly higher for control vs. treated quarters at both 1 to 3 DIM (29.1 vs. $22.8 \% ; P<0.05)$ and 6 to 8 DIM (25.9 vs. $20.6 \%$; $P<0.05$ ) (Table 1 ). The odds of having an IMI present at 1 to 3 DIM were $31 \%$ lower for treated vs. control quarters at 1 to 3 DIM $[-0.37 \pm 0.11 ;$ O.R.tx $=0.69(0.56,0.85) ; P=0.0008]$ and $26 \%$ lower for treated vs. control quarters at 6 to 8 DIM $[-0.30 \pm 0.11 ;$ O.R.tx $=0.74(0.60,0.91) ; P=$ 0.004] (see Table 4).

Quarters dried off during the months of May or June were at significantly higher risk for presence of an IMI (overall) after calving than the month of August (referent) $(P<0.05)$. In univariate analysis both the presence of an IMI at dry off and LS at dry off were each associated with an increased risk for an IMI to be present at 1 to 3 DIM $(P<0.05)$. However, when included together in the multivariate model, the pres- 
Table 1. Prevalence of IMI and description of bacterial species present in control (DCT) and treated (DCT + Orbeseal) quarters at dry off, 1 to 3 DIM, and 6 to 8 DIM. ${ }^{1}$

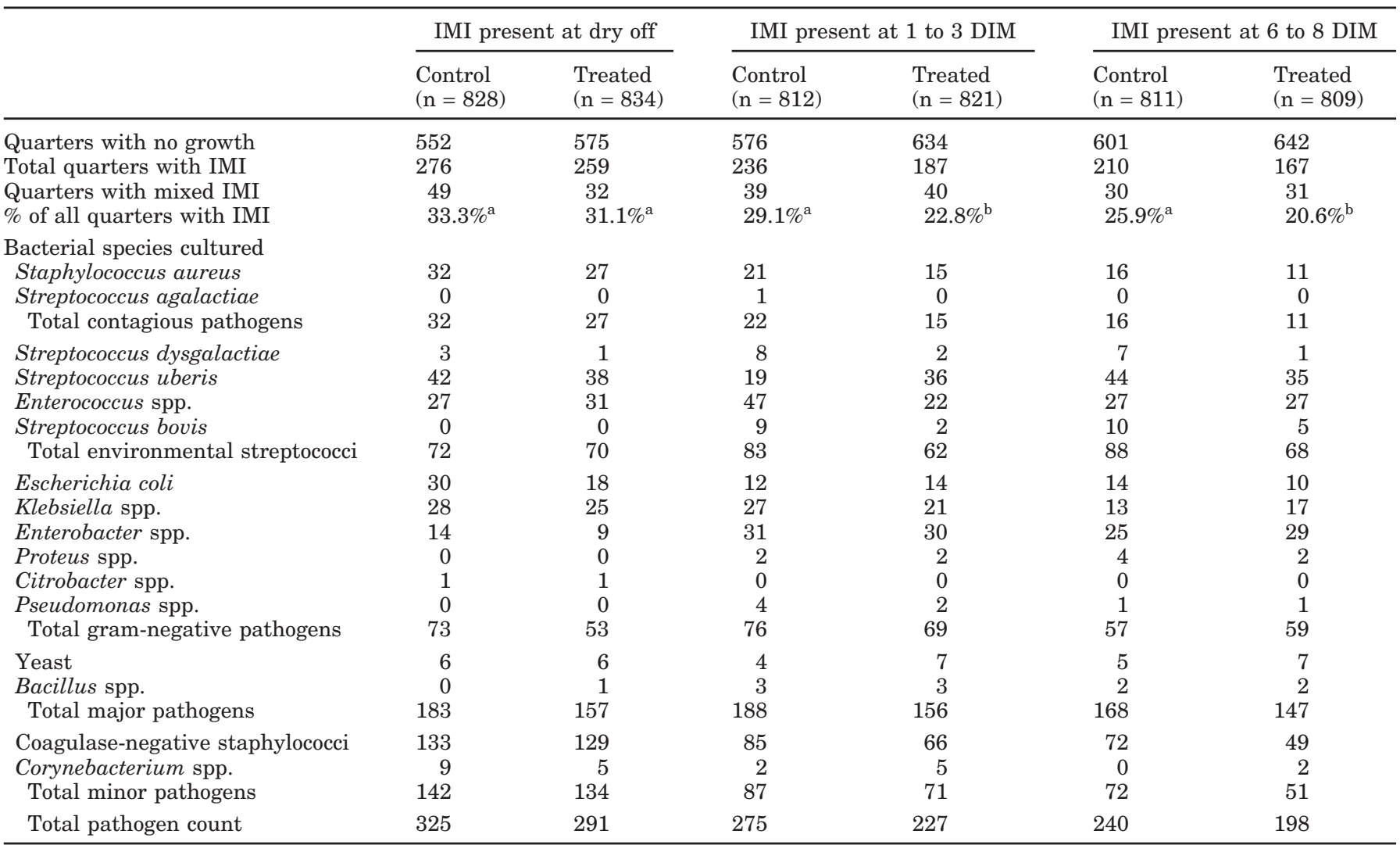

a,b\% of all quarters with IMI between columns are significantly different $(P<0.05)$.

${ }^{1}$ Note: reports all species cultured from quarters with single and mixed infections.

ence of an IMI at dry off was no longer significant $(P$ $=0.16)$. The latter model was selected because it yielded a better model fit according to the log-likelihood ratio. Covariates describing herd, parity, days dry, and milk yield (kg/d) at dry off were not significant in these models $(P>0.05)$. No interactions existed between Orbeseal treatment and any other covariates.

Further regression analysis showed that treatment with Orbeseal was associated with a significant reduction in risk for presence of an IMI at 1 to 3 DIM for the following general pathogen subgroups: major pathogens, minor pathogens, and environmental streptococci. There was no effect of treatment on prevalence of IMI at 1 to 3 DIM when considering IMI caused by either contagious pathogens or gram-negative species (see Table 4).

\section{Effect of Treatment on Risk for Developing a New IMI Between Dry Off and 1 to 3 DIM, or Between Dry Off and 6 to 8 DIM}

The proportion of quarters developing a new IMI (overall) was significantly lower for treated vs. control quarters when assessed at 1 to 3 DIM (20.2 vs. 25.4\%; $P<0.05$ ), and also tended to be lower when assessed at 6 to 8 DIM ( 18.8 vs. $21.7 \% ; P<0.10)$ (Table 2$)$. The odds of developing a new IMI (overall) between dry off and 1 to 3 DIM were $30 \%$ lower for treated vs. control quarters $[-0.36 \pm 0.11 ;$ O.R.tx $=0.70(0.56,0.87) ; P=$ 0.002] (Table 4).

In the final multivariate model, the presence of an IMI at dry off was associated with an increase in risk for acquiring a new IMI (overall) by 1 to 3 DIM (0.31 $\pm 0.16 ; P<0.05)$. More specifically, this association was related to previous IMI with a major pathogen, but not a minor pathogen. Quarters dried off during the months of May or June were at significantly higher risk for developing a new IMI between dry off and 1 to 3 DIM, compared with quarters dried off during the month of August (referent) $(P<0.05)$. Furthermore, there was a positive association between LS at dry off and risk for developing a new IMI by 1 to 3 DIM (0.08 $\pm 0.04 ; P=0.05$ ), even when controlling for IMI status at dry off in the same model. This increased LS could have represented the presence of an IMI that went undetected with culture. Another possibility is that it 
Table 2. Description of bacterial species isolated in new intramammary infections from control (DCT) and treated (DCT + Orbeseal) quarters at 1 to 3 DIM and 6 to 8 DIM. $^{1}$

\begin{tabular}{|c|c|c|c|c|}
\hline & \multicolumn{2}{|c|}{$\begin{array}{l}\text { New IMI acquired between } \\
\text { dry off and } 1 \text { to } 3 \text { DIM }\end{array}$} & \multicolumn{2}{|c|}{$\begin{array}{l}\text { New IMI acquired between } \\
\text { dry off and } 6 \text { to } 8 \text { DIM }\end{array}$} \\
\hline & $\begin{array}{l}\text { Control } \\
(\mathrm{n}=812)\end{array}$ & $\begin{array}{l}\text { Treated } \\
(\mathrm{n}=821)\end{array}$ & $\begin{array}{l}\text { Control } \\
(\mathrm{n}=811)\end{array}$ & $\begin{array}{l}\text { Treated } \\
(\mathrm{n}=809)\end{array}$ \\
\hline Number of quarters with new IMI & 206 & 166 & 176 & 152 \\
\hline Number of quarters with mixed new IMI & 34 & 36 & 21 & 27 \\
\hline$\%$ of quarters with new IMI & $25.4 \%^{\mathrm{a}}$ & $20.2 \%^{\mathrm{b}}$ & $21.7 \%{ }^{\mathrm{a}}$ & $18.8 \%{ }^{\mathrm{c}}$ \\
\hline \multicolumn{5}{|l|}{ Bacterial species cultured in new IMI } \\
\hline Staphylococcus aureus & 10 & 7 & 6 & 4 \\
\hline Streptococcus agalactiae & 2 & 0 & 0 & 0 \\
\hline Total contagious pathogens & 12 & 7 & 6 & 4 \\
\hline Streptococcus dysgalactiae & 8 & 2 & 7 & 1 \\
\hline Streptococcus uberis & 18 & 35 & 38 & 32 \\
\hline Enterococcus spp. & 46 & 22 & 25 & 25 \\
\hline Streptococcus bovis & 9 & 2 & 10 & 5 \\
\hline Total environmental streptococci & 81 & 61 & 80 & 63 \\
\hline Escherichia coli & 11 & 14 & 13 & 10 \\
\hline Klebsiella spp. & 26 & 19 & 11 & 16 \\
\hline Enterobacter spp. & 28 & 29 & 24 & 29 \\
\hline Proteus spp. & 2 & 2 & 4 & 2 \\
\hline Citrobacter spp. & 0 & 0 & 0 & 0 \\
\hline Pseudomonas spp. & 4 & 2 & 1 & 1 \\
\hline Total gram-negative pathogens & 71 & 66 & 53 & 58 \\
\hline Yeast & 4 & 7 & 5 & 7 \\
\hline Bacillus spp. & 3 & 3 & 2 & 2 \\
\hline Total major pathogens & 171 & 144 & 146 & 134 \\
\hline Coagulase-negative staphylococci & 67 & 53 & 51 & 43 \\
\hline Corynebacterium spp. & 2 & 5 & 0 & 2 \\
\hline Total minor pathogens & 69 & 58 & 51 & 45 \\
\hline Total pathogen count & 240 & 202 & 197 & 179 \\
\hline
\end{tabular}

was a residual elevation in LS in a quarter that had recently eliminated an IMI, and that the same unexplained variable that had predisposed the teat to the earlier IMI would also predispose it to an increased risk for a new IMI during the dry period (e.g. teat end condition). Other covariates describing herd, parity, days dry, and milk yield at dry off were not significant covariates in these models $(P>0.05)$. No interactions existed between Orbeseal treatment and any other covariates.

Further regression analysis showed that treatment with Orbeseal was associated with a significant reduction in the risk for developing a new IMI by 1 to 3 DIM for the major pathogen and environmental streptococci pathogen groups. The was also a strong tendency for a reduction in the incidence of new IMI caused by minor pathogens $(P=0.08)$. However, there was no effect of treatment on incidence of new IMI caused by either contagious or gram-negative pathogens (Table 4).

\section{Effect of Treatment on Risk of Experiencing a Clinical Mastitis Event Between Dry Off and 60 DIM}

The proportion of quarters experiencing a clinical mastitis event between dry off and 60 DIM was significantly lower for treated (5.9\%) vs. control quarters $(8.0 \%)(P<0.05)$ (Table 3$)$. Of the 69 cases and 51 cases occurring in control and treated quarters, respectively, only 2 control quarters and 1 treated quarter experienced a case during the dry period, occurring at 4,6 , and $44 \mathrm{~d}$ precalving, respectively. All remaining cases occurred after calving. The odds of experiencing a case of clinical mastitis (overall) between dry off and 60 DIM were $33 \%$ lower for treated vs. control quarters $\left[O . R_{\text {tx }}=0.67(0.48,0.93) ; P=0.02\right]$ (Table 5). Survival analysis using the Cox proportional hazards regression model produced an identical estimate for odds of failure in treated quarters by $60 \mathrm{DIM}(-0.40 \pm 0.16$; hazard ratio $=0.67 ; P<0.05)($ Figure 1$)$.

In the final multivariate logistic regression model, the presence of an IMI with a major, but not a minor, 
Table 3. Description of pathogens cultured from control quarters (DCT) and treated quarters (DCT plus Orbeseal) for clinical mastitis events occurring between dry off and 60 DIM. $^{1}$

\begin{tabular}{lcc}
\hline $\begin{array}{l}\text { Organism cultured } \\
\text { from clinical mastitis event }\end{array}$ & $\begin{array}{c}\text { Control quarters } \\
\mathrm{n}(\% \text { of all affected })\end{array}$ & $\begin{array}{c}\text { Treatment quarters } \\
\mathrm{n}(\% \text { of all affected) }\end{array}$ \\
\hline Staphylococcus aureus & $3(4.3)$ & $3(5.9)$ \\
Environmental streptococci & $17(24.6)$ & $3(5.9)$ \\
Escherichia coli & $11(15.9)$ & $8(15.7)$ \\
Klebsiella spp. & $1(1.4)$ & $4(7.8)$ \\
Pseudomonas spp. & $0(0)$ & $1(2.0)$ \\
Total gram-negative pathogens & $12(17.4)$ & $13(25.5)$ \\
Total major pathogens & $32(46.4)$ & $19(37.3)$ \\
Coagulase-negative staphylococci & $7(10.1)$ & $9(17.6)$ \\
Corynebacterium spp. & $1(1.4)$ & $0(0)$ \\
Total minor pathogens & $8(11.6)$ & $9(17.6)$ \\
Total pathogens identified & $40(58.0)$ & $28(54.9)$ \\
No growth & $14(20.3)$ & $10(19.6)$ \\
Contaminated sample & $0(0)$ & $1(2.0)$ \\
No results available & $15(21.7)$ & $12(23.5)$ \\
Total affected & $69(100)$ & $51(100)$ \\
Total at risk & 862 & 862 \\
$\%$ of total affected & $8.0 \% \%^{\mathrm{a}}$ & $5.9 \%$ \\
\hline
\end{tabular}

a,b\% of all quarters with a clinical mastitis event between columns significantly different $(P<0.05)$.

${ }^{1}$ Note: Only first clinical mastitis event is reported for any one quarter.

Table 4. Results of multivariate regression analysis of odds for presence of an IMI at 1 to 3 DIM and odds of acquiring a new IMI between dry off and 1 to 3 DIM for control quarters (DCT) and treated quarters (DCT plus Orbeseal). ${ }^{1}$

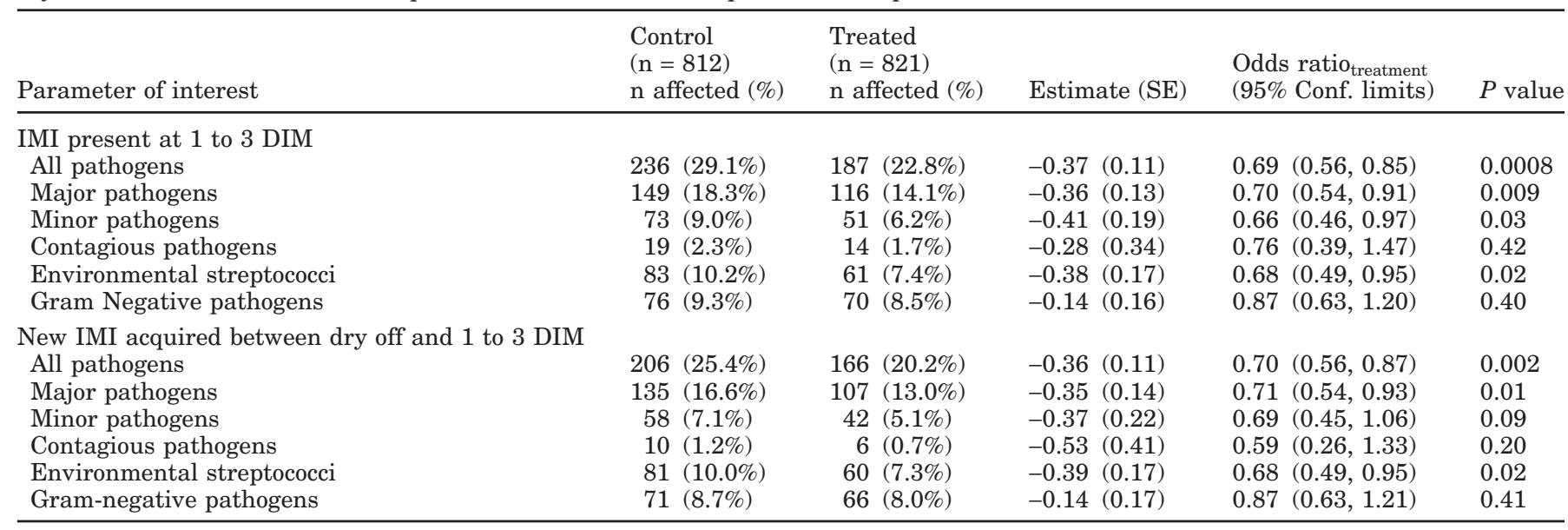

${ }^{1}$ Models control for herd, parity, month, linear score, and infection status at dry off.

Table 5. Results of multivariate regression analysis of odds for experiencing a clinical mastitis event between dry off and 60 DIM for control quarters (DCT) and treated quarters (DCT plus Orbeseal). ${ }^{1}$

\begin{tabular}{lclllll}
\hline & $\begin{array}{l}\text { Control } \\
(\mathrm{n}=862) \\
\mathrm{n} \text { affected }(\%)\end{array}$ & $\begin{array}{l}\text { Treatment } \\
(\mathrm{n}=862) \\
\mathrm{n} \text { affected }(\%)\end{array}$ & Estimate (SE) & $\begin{array}{l}\text { Odds ratio } \\
\text { (95\% Conf. limits })\end{array}$ & $P$ value \\
\hline Pll pathogen cultured & $69(8.0 \%)$ & $51(5.9 \%)$ & -0.40 & $(0.17)$ & $0.67(0.48,0.93)$ & 0.02 \\
Major pathogens & $32(3.7 \%)$ & $19(2.2 \%)$ & -0.73 & $(0.28)$ & $0.48(0.28,0.83)$ & 0.008 \\
Minor pathogens & $8(0.9 \%)$ & $9(1.0 \%)$ & -0.02 & $(0.44)$ & $0.98(0.42,2.30)$ & 0.96 \\
Contagious pathogens & $3(0.4 \%)$ & $3(0.4 \%)$ & $0.006(0.70)$ & $1.01(0.25,4.0)$ & 0.99 \\
Environmental streptococci & $17(2.0 \%)$ & $3(0.4 \%)$ & -1.79 & $(0.68)$ & $0.17(0.04,0.63)$ & 0.0009 \\
Gram Negative pathogens & $12(1.4 \%)$ & $13(1.5 \%)$ & $-0.057(0.41)$ & $0.94(0.43,2.10)$ & 0.89 \\
\hline
\end{tabular}

${ }^{1}$ Models control for herd, days dry, and parity, month, linear score, and infection status at dry off. 


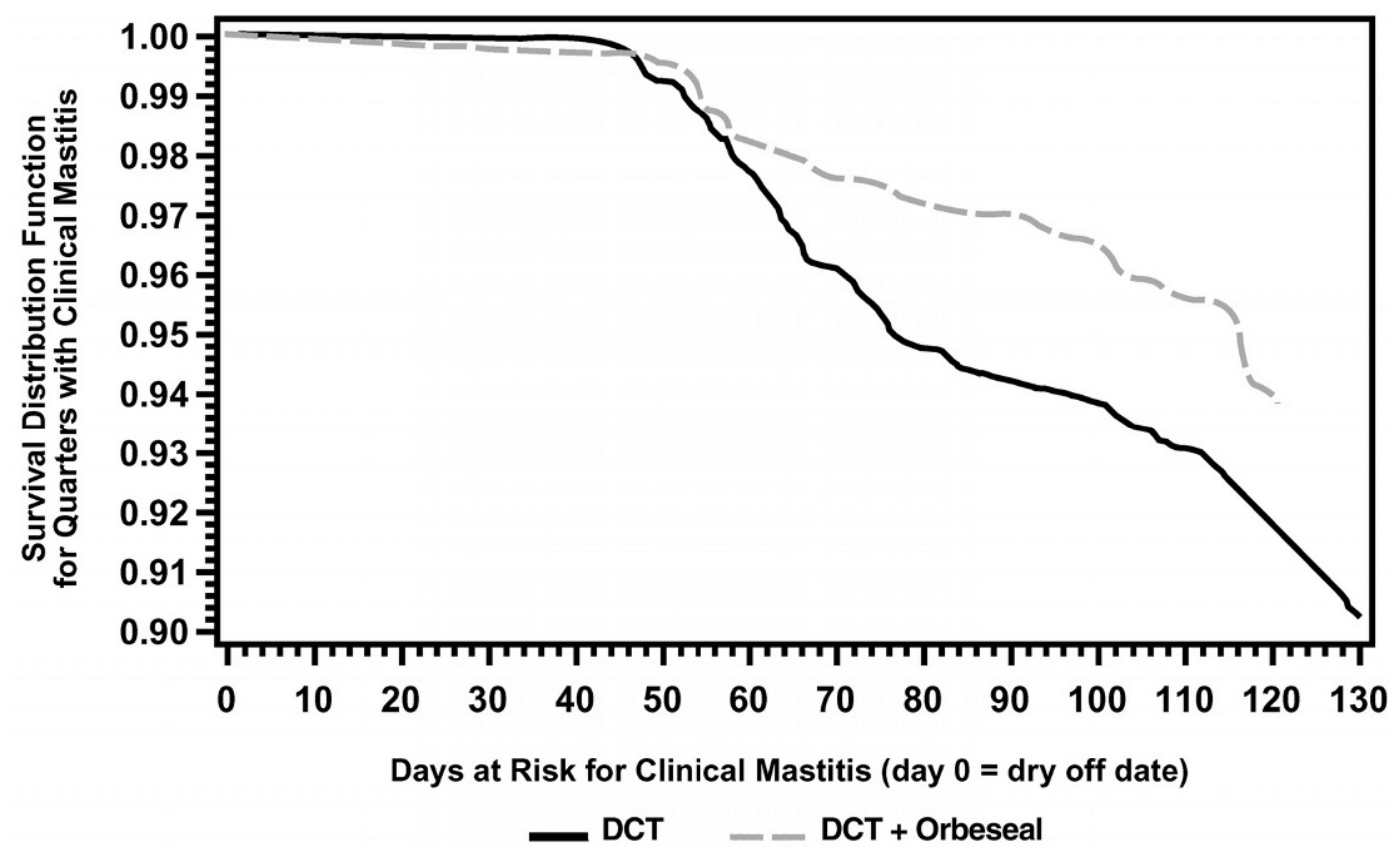

Figure 1. Survival distribution function for days to a clinical mastitis event between dry off (day 0) and 60 DIM (censor date), for quarters treated with dry cow antibiotic therapy (DCT) or DCT plus Orbeseal. Cox proportional hazard regression model controls for herd, month of dry off, days dry, parity, infection status at dry off, and linear score at dry off.

pathogen species at dry off was associated with an increase in risk for a clinical mastitis event by $60 \mathrm{DIM}$ $(0.63 \pm 0.22 ; P<0.05)$. Also, LS at dry off had a positive association with risk for a clinical mastitis event $(0.20$ $\pm 0.06 ; P<0.05)$. Quarters dried off during the months of May, June, or July were at significantly higher risk for clinical mastitis than for the month of August (referent) $(P<0.05)$. Finally, there was a strong tendency for cows with longer days dry to be at increased risk for a clinical mastitis event $(0.04 \pm 0.02 ; P=0.06)$. Variables describing parity and milk yield at dry off were not significant in these models $(P>0.05)$. No interactions existed between Orbeseal treatment and any other covariates.

Further regression analysis showed that treatment with Orbeseal was associated with a significant reduction in the risk for a clinical mastitis event between dry off and 60 DIM for clinical cases caused by the major pathogen and environmental streptococci pathogen groups. There was no effect of treatment on the incidence of clinical cases caused by minor pathogens, contagious pathogens, or gram-negative pathogens (Table 5).

\section{Effect of Treatment on Linear Score at 1 to 3 DIM and 6 to 8 DIM}

Quarters treated with Orbeseal had a significantly lower mean LS at both 1 to 3 DIM and 6 to 8 DIM
(LSmean $=5.1 \pm 0.17$ and $2.8 \pm 0.18)$ than for control quarters $(\mathrm{LSmean}=5.4 \pm 0.17$ and $3.1 \pm 0.18)(P<$ 0.0001). There was a positive association between LS at dry off and LS at both 1 to 3 DIM $(0.17 \pm 0.03 ; P<$ $0.05)$ and 6 to 8 DIM $(0.19 \pm 0.03 ; P<0.05)$. Also, the presence of an IMI at dry off caused by a major, but not a minor, pathogen species was associated with an increase in LS at 1 to 3 DIM $(0.27 \pm 0.10 ; P<0.05)$ and at 6 to 8 DIM $(0.19 \pm 0.10 ; P<0.05)$. Quarters dried off during the months of April or May had a significantly lower LS than for August (referent) $(P<$ $0.05)$. Parity had a positive effect on LS at 1 to 3 DIM $(0.20 \pm 0.05 ; P<0.05)$ and 6 to $8 \mathrm{DIM}(0.13 \pm 0.05 ; P$ $<0.05)$. Days dry had a negative association with LS at both 1 to $3 \mathrm{DIM}$ and 6 to $8 \mathrm{DIM}(-0.03 \pm 0.008 ; P$ $<0.05)$. Neither herd nor milk yield at dry off were significant covariates in these models. No interactions existed between Orbeseal treatment and these other covariates.

\section{Effect of Treatment on Risk for Experiencing a Cure Between Dry Off and 1 to 3 DIM}

The proportion of quarters experiencing a cure (overall) between dry off and 1 to 3 DIM was not different between treated quarters $(91.3 \%)$ and control quarters $(88.2 \%)(P>0.05)$. There was a significantly lower risk for a cure if the IMI infection at dry off was caused by a contagious pathogen $(-1.28 \pm 0.35 ; P<$ 
0.05), compared with IMI caused by other pathogen groups. There was a negative relationship between LS at dry off and risk for a cure by 1 to 3 DIM $(-0.25 \pm$ $0.08 ; P<0.05)$. No other covariates tested were associated with risk for an apparent cure between dry off and 1 to 3 DIM.

\section{DISCUSSION}

This is the first study performed in North America to test the efficacy of an internal teat seal as an adjunct to DCT to prevent new IMI during the dry period. The results of this study demonstrate that the additional infusion with Orbeseal had a significant effect on reducing the risk for acquiring a new IMI between dry off and 1 to 3 DIM, reducing the prevalence of IMI at both 1 to 3 and 6 to 8 DIM, reducing the risk for experiencing a clinical mastitis event between dry off and $60 \mathrm{DIM}$, and reducing LS at both 1 to 3 and 6 to 8 DIM. The odds of an Orbeseal-treated quarter acquiring a new IMI between dry off and 1 to 3 DIM, having an IMI present at 1 to 3 DIM, or experiencing a clinical mastitis event between dry off and 60 DIM, were reduced by an estimated 30,31 , and $33 \%$, respectively, compared with control quarters. The protective effect of Orbeseal treatment is presumed to be mediated by acting as a functional keratin plug and so reducing access to the gland by environmental pathogens.

There was no treatment effect when considering IMI caused by contagious mastitis pathogens (primarily Staph. aureus in this study). This may be explained by the fact that cows are at a reduced risk for transmission of contagious pathogens during the dry period. Rather, the protective effect of treatment was mediated primarily through a reduction in the rate of new IMI caused by both major and minor pathogen groups, and particularly by the some of the environmental streptococci species. While no analysis was performed for any one specific bacterial species, the latter relationship appeared to be driven by a numerical reduction in new IMI caused by Staph. dysgalactia, Strep. bovis, and Enterococcus spp., but not Strep. uberis. In fact, there was a numerical increase in treated quarters for new IMI caused by Strep. uberis. It is uncertain why there should be a difference between these species, since all are thought to be acquired primarily from the environment (N.M.C., 1999).

Similarly, it is not clear why there was no treatment effect observed when considering the gram-negative pathogen group, particularly when Huxley et al. (2002) reported that treatment of uninfected quarters with teat seal resulted in significantly fewer new IMI caused by $E$. coli and all Enterobacteriaciae, compared with uninfected quarters treated with antibiotic alone. Possible explanations for differences between this and the Huxley et al. (2002) study could include that the latter study was of a very different population of quarters and cows (targeted uninfected cows and quarters), used a different study design, and may have been in herds and/or climates with exposure to a different pathogen profile mix. The current study found no interaction between treatment effectiveness and covariates such as LS, IMI, or milk yield at dry off. However, it is possible that, teat seal treatment aside, there may be differences between studies with regards to some of these other factors that could affect the risk for new IMI by a particular bacterial species or group during the dry period. This could include cow factors at dry off such as IMI status (overall), IMI status for specific pathogen species or groups (e.g., minor pathogen species), LS, immune system function, milk production, or teat end condition. This could also include differences in herd management factors such as dry cow housing environment, bedding type, season, ambient temperature, humidity, nutrition, vaccination programs, and possibly the spectrum of activity or duration of action of the dry cow antibiotic selected. These factors could create differences in teat-end exposure to different bacterial species or groups, as well as differences in the cow/quarter's ability to defend against pathogen invasion or eliminate infection caused by specific bacterial species. Published studies have not addressed whether the effectiveness of Orbeseal varies if used with different commercially available preparations of long-acting antibiotics. Furthermore, while it was not recorded in this study, future studies should seek to describe if the teat seal is still present in the teat at the time of calving.

The ideal postcalving sampling point for culture would have occurred at the first milking when the Orbeseal was stripped out, as the estimate of new IMI occurring between dry off and the 1 to 3 DIM sampling point could be influenced by some cures or new IMI occurring after removal of the teat seal. However, there were concerns about sample quality, as a several different facility staff routinely processed fresh cows. Therefore it was decided that the same study technician would collect postfresh samples at both the 1 to 3 DIM and 6 to 8 DIM sampling points. The estimate of risk for acquiring a new IMI calculated using the samples collected at 1 to 3 DIM is expected to be more accurate than the estimate produced using the samples collected at 6 to 8 DIM, as some additional new IMI and cures would be expected to have occurred between the 1 to 3 DIM and 6 to 8 DIM sampling points. 
Previous research on accuracy of the on-farm triplate culture system (Minnesota Easy Culture System II) has demonstrated that very good agreement occurred in differentiating between general pathogen categories when the technician is provided with training and specific protocols to guide interpretation (Bey and Farnsworth, 2000). Errors that did occur were often the result of attempting to "over-read" the identification system (e.g., trying to differentiate between a Strep. uberis vs. an Enterococcus spp.). With this in mind, the authors took a conservative approach to the analysis of clinical mastitis data by investigating the relationship between treatment and both the total number of cases (overall) and cases caused by broader pathogen subgroups. As such, there is good confidence in the validity of the study results and inferences investigating the relationship between treatment and clinical mastitis events.

Dry period cure rates for this study were similar to the study by Huxley et al. (2002), which reported a cure rate of $93.6 \%$ in quarters receiving antibiotic alone. Similar to results reported by Huxley et al. (2002), the current study found no effect of Orbeseal treatment on risk for an apparent cure between dry off and 1 to 3 DIM. This is logical given that the product contains no antimicrobial properties, and given that all 4 quarters were treated with DCT.

It was not an objective of this study to describe associations between other covariates and the dependent variables of interest, but rather simply to control for them in the analyses. However, there were some interesting associations identified, many of which have been reported in previous studies. For example, quarters dried off in the months of May or June were at higher risk, than quarters dried off in August (referent), for having an IMI present at 1 to 3 DIM, acquiring a new IMI between dry off and 1 to 3 DIM, and experiencing a clinical mastitis event between dry off and 60 DIM. An explanation for this could be that the heat and humidity of the summer months could have contributed to a greater pathogen load in the environment. Heat stress could also have compounded the degree of immunosupression that frequently occurs in periparturient cows, resulting in a reduced ability to eliminate infection if a pathogen did invade the gland and/or increased shedding from infected glands (Nardone et al., 1997; Mallard et al., 1998; Kimura et al., 1999). Furthermore, heat stress, changes in nutritional management, or other management changes occurring during this period could contribute to the development of other metabolic diseases in the periparturient period, which can then affect immune function (Kehrlie et al., 1990; Zerbe et al., 2000). A final contributing factor could be differences in the types of facili- ties (free stall, pasture) where far-off dry cows were housed. Unfortunately, this hypothesis could not be investigated because the study did not capture records describing each cow's far-off housing location or how long she stayed at that location.

Readers should be cautious about extrapolating the results of this study, performed in 2 purposively selected herds, to other dairy herds. Results from ongoing internal teat seal studies in multiple herds in Canada and the United States will be necessary to determine if the levels of subclinical and clinical mastitis and the magnitude of treatment response observed in this study are representative of other commercial North American dairy herds. Readers should also be cautious about making direct comparisons between the results of this study and other recent teat seal studies performed in New Zealand (Woolford et al., 1998) and the United Kingdom (Berry and Hillerton, 2002; Huxley et al., 2002), given the very different nature of the study populations used, study designs, and objectives. In particular, these earlier studies targeted the use of this internal teat seal as the sole treatment in uninfected quarters, as compared to either DCT as sole treatment, or no treatment. It is reassuring that there is some consistency, in terms of IMI prevalence and rates, between this and at least one other study: The overall prevalence of IMI (all quarters) at dry off for quarters in the current study was $32.2 \%$, compared with an average of $37.6 \%$ for all quarters included in the Huxley et al. (2002) study. Similarly, the current study reported an incidence of new IMI in antibiotic-treated quarters of $25.4 \%$, as compared to $39.3 \%$ in antibiotic-treated quarters in the Huxley et al. (2002) study. By contrast, however, Woolford et al. (1998) reported only a $2.3 \%$ new IMI rate in antibiotic-treated quarters in three New Zealand herds. It is clear that more studies are needed to describe if the results of the current study will be repeated in other commercial North American dairy herds. Similarly, further studies with treatment applied at the cow-level, and not the quarter-level, will be necessary to accurately determine whether the biological benefits associated with using an internal teat seal in addition to an antibiotic are cost effective. Economic benefits measured at the cow-level could include lowered SCC and associated milk quality premiums, a reduction in milk lost due to reduced rates of subclinical mastitis, and a reduction in costs associated with lower clinical mastitis rates, including discarded milk, drug costs, labor, veterinary fees, culling, death, genetic loss, and antimicrobial residue risks (Fetrow et al., 2000). 


\section{CONCLUSIONS}

The results of this study demonstrate that infusion with Orbeseal as an adjunct to DCT at dry off had a significant effect on reducing the risk for acquiring a new IMI between dry off and 1 to 3 DIM, reducing the risk for presence of an IMI at both 1 to 3 and 6 to 8 DIM, reducing the risk for experiencing a clinical mastitis event between dry off and 60 DIM, and reducing LS at both 1 to 3 and 6 to 8 DIM. Quarters treated with Orbeseal and DCT were $30 \%$ less likely to develop a new IMI between dry off and 1 to 3 DIM, 31\% less likely to have an IMI present at 1 to 3 DIM, 33\% less likely to experience a clinical mastitis event between dry off and 60 DIM, and had significantly lower LS measurements at both 1 to 3 and 6 to 8 DIM, as compared to quarters treated with DCT alone. While further studies are needed to determine if similar performance can be attained in other commercial North American dairy herds, and to accumulate data defining the cost-benefit of using the teat seal as an adjunct to DCT at dry off, the results of this study suggest that Orbeseal is very promising as an additional management tool to assist in the prevention of new intramammary infections during the dry period.

\section{ACKNOWLEDGMENTS}

This study was funded by Pfizer Animal Health, Inc. (New York, NY). Many thanks to Jody Olson for all of her hard work treating and sampling cows and maintaining study records. Thanks also to the staff at the Laboratory for Udder Health (Minnesota Veterinary Diagnostic Laboratory, University of Minnesota, St. Paul, MN) and to Muril Niebuhr (Zumbrota MN DHIA laboratory, Zumbrota, MN), for their extra effort in assisting with sample analysis and the transfer of data. Finally, a sincere thanks to the owners and staff at Emerald Dairy, Baldwin Dairy, and Emerald II (TMF) for their willingness to participate in this study.

\section{REFERENCES}

Beatty, B., R. Farnsworth, A. Lund, R. Lyon, and G. Ward. 1985. Medium to culture and differentiate coagulase-positive and -negative staphylococci from bovine milk. J. Food Prot. 48:1019-1021.

Berry, E. A., and J. E. Hillerton. 2002. The effect of an intramammary teat seal on new intramammary infections. J. Dairy Sci. 85:2512-2520.

Bey, R., and R. Farnsworth. 2000. Cow side microbiology. Pages 97-98 in Proc. Annu. Meet. of the Minnesota Dairy Health Management Conference. May 23-25, 2000. St. Paul, MN.

Bradley, A. J., and M. J. Green. 2001. An investigation of the impact of intramammary antibiotic dry cow therapy on clinical coliforms mastitis. J. Dairy Sci. 84:1632-1639.
Bradley, A. J., and M. J. Green. 2000. A study of the incidence and significance of intramammary Enterobacterial infections acquired during the dry period. J. Dairy Sci. 83:1957-1965.

Browning, J. W., G. A. Mein, M. Barton, T. J. Nicholls, and P. Brightling. 1990. Effects of antibiotic therapy at drying off on mastitis in the dry period and early lactation. Aust. Vet. J. $67: 440-442$.

Buelow, K., W. Goodger, M. Collins, M. Clayton, K. Nordlund, and C. Thomas. 1996. A model to determine sampling strategies and milk inoculum volume for detection of intramammary Staphyolococcus aureus infections in dairy cattle by bacteriological culture. Prev. Vet. Med. 25:343-355.

Committee for Veterinary Medical Products. 1999. Bismuth subnitrate (extension to intramammary route) (EMEA/CVMP/705/ 00-Final). The European Agency for the Evaluation of Medicinal Products.

Comalli, M. P., R. J. Eberhart, L. C. Griel, Jr., and H. Rothenbacher. 1984. Changes in the microscopic anatomy of the bovine teat canal during mammary involution. Am. J. Vet. Res. 45:22362242.

Dingwell, R. T., L. L. Timms, J. M. Sargeant, D. F. Kelton, Y. H. Schukken, and K. E. Leslie. 2003. The association of teat canal closure and other risk factors for new dry period intramammary infections. Pages 298-299 in Proc. 42nd Annu. Mtg. National Mastitis Council, Inc., Madison WI. Mtg. Natl. Mastitis Counc., Forth Worth, TX.

Eberhart, R. J. 1986. Management of dry cows to reduce mastitis. J. Dairy Sci. 69:1721-1732.

Erskine, R. J., and R. J. Eberhart. 1988. Comparison of duplicate and single quarter milk samples for identification of intramammary infections J. Dairy Sci. 71:854-856.

Fetrow, J., S. Stewart, S. Eicker, R. Farnsworth, and R. Bey. 2000. Mastitis: an economic consideration. Pages 3-47 in Proc. 39th Annu. Mtg. Natl. Mastitis Counc., Atlanta, GA. National Mastitis Council, Inc., Madison, WI.

Green, M. J., L. E. Green, G. F. Medley, Y. H. Schukken, and A. J. Bradley. 2002. Influence of dry period bacterial intramammary infection on clinical mastitis in dairy cows. J. Dairy Sci. 85:2589-2599.

Hogan, J. S., and K. L. Smith. 1998. Risk factors associated with environmental mastitis. Pages 93-94 in Proc. 37th Annu. Mtg. Natl. Mastitis Counc., St. Louis, MO. National Mastitis Council, Inc., Madison, WI.

Huxley, J. N., M. J. Green, L. E. Green, and A. J. Bradley. 2002. Evaluation of the efficacy of an internal teat sealer during the dry period. J. Dairy Sci. 85:551-561.

Kehrli, M. E., Jr., J. P. Goff, J. A. Harp, and J. R. Thurston. 1990. Effects of preventing periparturient hypocalcemia in cows by parathyroid hormone administration on hematology, conglutinin, immunoglobulin, and shedding of Staphylococcus aureus in milk. J. Dairy Sci. 73:2103-2111.

Kimura, K., J. P. Goff, and M. E. Kehrli, Jr. 1999. Effects of the presence of the mammary gland on expression of neutrophil adhesion molecules and myeloperoxidase activity in periparturient dairy cows. J. Dairy Sci. 82:2385-2392.

Lam, T. J. G. M., L. A. van Wuijckhuise, P. Franken, M. L. Morselt, E. G. Hartman, and Y. A. Schukken. 1996. Use of composite milk samples for diagnosis of Staphylococcus aureus mastitis in dairy cattle. J. Am. Vet. Med. Assoc. 208:1705-1708.

Lim, G. H., K. E. Leslie, J. Morgan, B. Dow, D. Kelton, T. F. Duffield, and J. TenHag. 2000. An evaluation of the factors affecting the efficacy of a dry cow teat seal. Pages 245-246 in Proc. 39th Annu. Meet. of the National Mastitis Council. National Mastitis Council, Madison, WI.

Leslie, K. E., K. J. Day, J. Tenhag, D. F. Kelton, T. F. Duffield, and T. L. Kerbler. 1999. Factors affecting the adherence of a dry cow teat seal. Pages 136-137 in Proc. 38th Annu. Mtg. Natl. Mastitis Counc., Arlington, VA. National Mastitis Council, Inc., Madison, WI.

Mallard, B. A., J. C. Dekkers, M. J. Ireland, K. E. Leslie, S. Sharif, C. Lacey Vankampen, L. Wagter, and B. N. Wilkie. 1998. Alteration in immune responsiveness during the peripartum period 
and its ramification on dairy cow and calf health. J. Dairy Sci. 81:585-595.

Minnesota Easy Culture System II Handbook. 2000. Laboratory for Udder Health, Minnesota Diagnostic Laboratory, University of Minnesota. St. Paul, MN.

National Mastitis Council: Laboratory Handbook on Bovine Mastitis. Revised Edition. 1999. Natl. Mastitis Counc., Inc., Madison, WI.

Nardone, A., N. Lacetera, U. Bernabucci, and B. Ronchi. 1997. Composition of colostrum from dairy heifers exposed to high air temperatures during later pregnancy and the early postpartum period. J. Dairy Sci. 80:838-844.

Natzke, R. P. 1981. Elements of mastitis control. J. Dairy Sci. 64:1431-1442.

Oliver, S. P., and L. M. Sordillo. 1989. Approaches to the manipulation of mammary involution. J. Dairy Sci. 72:1647-1664

SAS User's Guide: Statistics, Release 8.0. 2000. SAS Institute Inc., Cary, NC.

Smith, K. L., D. A. Todhunter, and P. S. Schoenberger. 1985. Environmental pathogens and intramammary infection during the dry period. J. Dairy Sci. 68:402-417.
Sargeant, J. M., K. E. Leslie, J. E. Shirley, B. J. Pulkrabek, and G. H. Lim. 2001. Sensitivity and specificity of somatic cell count and California Mastitis Test for identifying intramammary infection in early lactation. J. Dairy Sci. 84:2018-2024.

Timms, L. L. 1997. Field trial evaluation of a persistent barrier teat dip for preventing mastitis during the dry period. J. Dairy Sci. 80(Suppl. 1):225.

Todhunter, D. A., K. L. Smith, J. S. Hogan, and P. S. Schoenberger. 1991. Gram-negative bacterial infections of the mammary gland in cows. Am. J. Vet. Res. 52:184-188.

Williamson, J. H., M. W. Woolford, and A. M. Day. 1995. The prophylactic effect of a dry-cow antibiotic against Streptococcus uberis. N.Z. Vet. J. 43:228-234.

Woolford, M. W., J. H. Williamson, A. M. Day, and P. J. A. Copeman 1998. The prophylactic effect of a teat sealer on bovine mastitis during the dry period and the following lactation. N.Z. Vet. J. 46:12-19.

Zerbe, H., N. Schneider, W. Leibold, T. Wensing, T. A. M. Kruip, and H. J. Schuberth. 2000. Altered functional and immunophenotypical properties of neutrophilic granulocytes in postpartum cows associated with fatty liver. Theriogenology 54:771-786. 